\title{
Stock Price of Pandemic Covid-19 in Stock Market Performance
}

\author{
Musdalifah Azis, Burhanuddin*, Heni Rahayu \\ Department of Management, Faculty of Economics and Business, Mulawarman University, Samarinda, 75117, Indonesia
}

Received January 21, 2021; Revised March 11, 2021; Accepted March 23, 2021

\section{Cite This Paper in the following Citation Styles}

(a): [1] Musdalifah Azis, Burhanuddin, Heni Rahayu, "Stock Price of Pandemic Covid-19 in Stock Market Performance," Universal Journal of Accounting and Finance, Vol. 9, No. 2, pp. 184 - 190, 2021. DOI: 10.13189/ujaf.2021.090206.

(b): Musdalifah Azis, Burhanuddin, Heni Rahayu (2021). Stock Price of Pandemic Covid-19 in Stock Market Performance. Universal Journal of Accounting and Finance, 9(2), 184 - 190. DOI: 10.13189/ujaf.2021.090206.

Copyright $\bigcirc 2021$ by authors, all rights reserved. Authors agree that this article remains permanently open access under the terms of the Creative Commons Attribution License 4.0 International License

\begin{abstract}
This study provides an overview of the situation and condition of the share price of publicly listed companies on the Indonesia Stock Exchange (IDX) and the impact of the Covid-19 pandemic experienced by the investor community on the performance of the Indonesia capital market. The data collection of this research was carried out by survey techniques by giving online questionnaires to the respondents. This study uses semantic scale analysis to measure respondents' views about the share price of their portfolio, the impact of the pandemic, and the performance of the Indonesian capital market. We performed validity, reliability, and hypothesis tests in forming a well-fitted model. The results of this study indicate that all the variables studied are valid and reliable, the hypothesis of the proposed statement is accepted that meets the significance level of the F-test and t-test, meaning that the strength of the issuer's stock price and the impact of the Covid-19 pandemic. This is able to explain and influence the performance variables of the Indonesian capital market by $74.7 \%$ out of 100 respondents in 2020 .
\end{abstract}

Keywords Share Price, Covid-19, Semantic Scale, Stock Market Performance, Indonesia

\section{Introduction}

This study aims to provide a descriptive explorative picture of the recent situation and conditions experienced by investors concerning the impact of the Covid-19 pandemic which caused them to maintain a distance between the community of investors regarding the fluctuation of stock price movements of their issuers resulting in a slowdown in stock trading. Most of them did not trade their stocks because they saw the impact of the global pandemic which caused a lot of foreign investment to flow out of the Indonesian capital market, as a result, the Indonesian capital market often weakened the adjustment of trade administration mechanisms for Indonesian capital market players.

The impact of the Covid-19 can be seen and measured from the global economic risks that occur [33], the prudent behavior of investors transacting online independently, the fluctuation of the Jakarta Composite Index (JCI) movement in the Indonesian capital market, negative investor sentiment in the red zone, weakening of exchange rates, and cash outflow of foreign investment. These statements are measured using a semantic scale of 1-5 on the responses experienced by Indonesian investors, resided in Samarinda.

The company share price is usually measured quantitatively by using secondary data that show fluctuations in the movement on the JCI. In this study, the issuer's share price is measured qualitatively from the representative shares issued by the issuer to which investors respond as a perceived experience in conducting sale trading transactions (short-term buy). During the Covid-19 pandemic, the decline in share price movements of issuers hit all investors hard on all investors, both domestic investors and foreign investors individually and institutions [34]. Some or some share prices have not 
completely dropped due to the Covid19 pandemic, the share price of issuers has skyrocketed the highest, some of the certain share prices in the red zone provide opportunities for new investors to trade online independently, in fact, the decline in stock prices provides opportunity affordability to buy by new investors. Investors responded to the movement of issuer's share prices as a result of the impact of Covid-19, especially in the consumer sector and various industries, keeping the distance that is done by listed companies limits the space for stock investment to trade the sale and purchase price of shares, causing the market capitalization value to fall, due to falling and skyrocketing prices. particular stock. The large variety of stock price spreads provides an opportunity to hit Covid-19, but this is controlled and stable due to an increase in the average daily transaction value, an increase in the average daily transaction volume, an increase in the frequency of daily transactions [16], an increase in net selling transactions of foreign investors [17], and an increase in investors managing public funds [18], [19].

The performance of the Indonesian capital market in this study finds that the behavior of share repurchases [20], [21] by Issuers without first obtaining General Meeting of Shareholders (GMS) approval and the maximum number of shares resulting from repurchase is increased paid-in capital back to the issuer's working capital, making the issuer's stock market strength later become stronger. The Indonesian capital market which is dominated by foreign investors motivates issuers to make repurchases [13], [20] to prevent cash outflows by foreign investors. The power of share repurchases by the issuer has not been balanced with the strength of the flow of foreign investors' funds that dominate the issuer's share ownership. [15] The globalization of capital market risks during the Covid-19 pandemic has almost been felt and experienced by all existing capital markets, forcing the Indonesian capital market to make several improvements in reporting administration made by market players, including regarding the issue of extending the deadline for submitting reports and organizing routine activities. which is usually done by market participants. Some of these things have been carried out by the Indonesian capital market as a form of capital market performance efforts in anticipating adjustments made by several other capital markets in ASEAN and EUROPE [15], [22], [17], [18].

\section{Literature Review}

The dynamics of stock price fluctuations [6], [23], [22] listed companies listed on the Indonesia Stock Exchange (IDX) during the Covid-19 pandemic [24], [6], are felt and experienced is a major blow to all investors, both foreign investors [24] and domestic investors, as a result of the skyrocketing share price the most [2], [25] stock prices in the red zone [26], corona hitting the consumer \& miscellaneous industry sector [27], [28], the value of market capitalization also fell [29], [30], an increase in the average daily transaction value, an increase in the average daily transaction volume, an increase in the frequency of daily transactions [16], an increase in net selling transactions of foreign investors [17], and an increase in investors managing public funds [18], [19].

The impact of the Covid-19 pandemic [12] has occurred globally in all capital markets in the world, especially the Indonesian capital market which is predominantly dominated by foreign investors, domestic investors in Samarinda feel and experience that the impact of the Covid-19 pandemic has resulted in several things, namely the risk of economic slowdown global [31] due to physical distancing, which made investors more cautious in direct transactions, the JCI weakened in the Indonesian capital market to its lowest position of around 3 years, its lowest was suppressed by investors who took a safe position, dragged down by negative sentiment in the red zone affected by Covid-19, the weakening of the JCI is in line with the performance of other Asian stock market indices [32] which are compactly advancing in the red zone [8] - [11], the depreciation of the rupiah against the dollar overshadows the market, and the outflow of foreign investment funds [14] from the domestic stock market.

The performance of the capital market during the Covid-19 pandemic [13] experienced several dynamic consequences that were felt and experienced by investors, namely share buybacks [20], [21] by Issuers without first obtaining GMS approval, and the maximum number of shares from the buyback was increased by capital paid-up, the extension of the deadline for submission of Annual Financial Statements for Issuers and Public Companies, including Listed Companies, namely for two months from the deadline for submission, an extension of the deadline for submission of Interim Financial Statements I Year 2020 for Listed Companies for two months from the deadline for report submission as referred to in the IDX Regulations, the extension of the deadline for holding the Annual GMS by Issuers and Public Companies for two months. The GMS is held using the Electronic Proxy facility in the E-GMS system. Changes in Auto Rejection limits in the Trading Regulations on the Stock Exchange, and there is a ban on Short Selling Transactions for all Exchange Members starting March 2 (2020), until the deadline set by the OJK. Halt trading for 30 minutes in case the JCI has decreased. Adjustment of haircut values and risk calculations for better market stimulation.

\section{Methodology}

The study uses a population of investors in Indonesia who are members of the Forward Air Controller (FAC) Indonesia investor community, using purposive sampling 
in compiling the sample, with the criteria that they belong to a community of FAC Indonesia investors, that they are actively observing the movement of their shares owned in the IDX. The had carried out a sale or purchase transaction during the Covid-19 pandemic, the total sample was 100respondents. Data analysis tools used include validity test, reliability test, and hypothesis test.

The variables studied include issuer share prices listed on the IDX, the impact of the Covid-19, and the performance of the Indonesian Capital Market. This qualitative research uses primary data by conducting survey questionnaire questions to respondents using several indicators, namely 8 indicators of Issuer Stock Prices, 6 indicators of Covid-19, and 5 indicators of Indonesian capital market performance.

Based on Table 2, the items that are asked of respondents have an r-count greater than the r-table, so it can be said that the item is valid. Cronbach's alpha with $\mathrm{N}$ of 19 items of 0.926 is greater than 0.65 , so it can also be said that the item is reliable.

Table 1. Item-Total Statistics Validity Test

\begin{tabular}{|c|c|c|c|c|c|}
\cline { 2 - 5 } \multicolumn{1}{c|}{} & SMID & SVID & CI-TC & SMC & CA \\
\hline Highest Share Price (X11) & 66.5400 & 107.180 & .529 & .482 & .924 \\
\hline Share Prices in the Red Zone (X12) & 66.1500 & 108.674 & .490 & .422 & .925 \\
\hline Market Capitalization Value (X13) & 66.1900 & 107.186 & .522 & .433 & .924 \\
\hline Daily Transaction Increase (X14) & 66.4700 & 105.221 & .569 & .650 & .924 \\
\hline Daily Transaction Volume (X15) & 66.6100 & 104.058 & .641 & .800 & .922 \\
\hline Daily Transaction Frequency (X16) & 66.5300 & 104.938 & .656 & .717 & .921 \\
\hline Net Selling Transactions (X17) & 66.4100 & 104.265 & .703 & .601 & .920 \\
\hline Public Fund Investor (X18) & 66.3300 & 104.244 & .684 & .613 & .921 \\
\hline Global Economic Risk (X21) & 65.6100 & 112.745 & .283 & .394 & .928 \\
\hline Regional Negative Sentiment (X22) & 65.9900 & 109.222 & .500 & .512 & .925 \\
\hline ASIA Stock Exchange (X23) & 66.0400 & 107.170 & .582 & .554 & .923 \\
\hline IDR exchange rate (X24) & 65.7400 & 107.346 & .596 & .514 & .923 \\
\hline Foreign Flow Funds (X25) & 66.1100 & 103.957 & .642 & .638 & .922 \\
\hline Macroeconomic Assumptions (X26) & 65.9300 & 105.379 & .616 & .580 & .922 \\
\hline Shares Buyback (Y11) & 66.2900 & 103.562 & .737 & .649 & .920 \\
\hline Extension of Share Time (Y12) & 66.1600 & 104.196 & .741 & .668 & .920 \\
\hline Company Financial Statements (Y13) & 66.2100 & 106.046 & .686 & .722 & .921 \\
\hline Electronic Proxy Facility (Y14) & 66.1000 & 105.485 & .647 & .609 & .922 \\
\hline Short Selling Transactions (Y15) & 66.2500 & 104.270 & .680 & .659 & .921 \\
\hline
\end{tabular}

(Source: Authors calculation)

Information: Scale Mean if Item Deleted (SMID), Scale Variance if Item Deleted (SVID), Corrected Item-Total

Correlation (CI-TC), Squared Multiple Correlation (SMC), Cronbach's Alpha (CA)

Table 2. Reliability Statistics

\begin{tabular}{|c|c|c|}
\hline Cronbach's Alpha & CA on Standardized Items & N of Items \\
\hline .926 & .926 & 19 \\
\hline
\end{tabular}

(Source: Authors calculation) 


\section{Findings and Discussions}

This study used 100 respondents using semantic scale analysis 1-5 with the choice of agreeing and disagreeing with the statements given, the respondents answered questions for each variable studied based on what they felt and experienced while having and being active in stock transactions in the Indonesian capital market, especially the Stock Exchange. Indonesia.

The stock prices of issuers listed on the IDX during the Covid19, investors felt and experienced that the dynamics of stock movement fluctuations occurred as a result of $44 \%$ of the skyrocketing share prices, $46 \%$ of share prices in the red zone, corona hitting the consumer sector \& various industries, $44 \%$ decrease in market capitalization value, $45 \%$ increase in average daily transaction value, $48 \%$ increase in average daily transaction volume, $49 \%$ increase in daily transaction frequency, $47 \%$ increase in foreign investor net sell transactions, and $47 \%$ increase in managing investors public funds (see Table 3 ).

The impact of the Covid19 has occurred globally in all capital markets in the world, especially the Indonesian capital market which is predominantly dominated by foreign investors, domestic investors in Samarinda feel and experience that the impact of the Covid- 19 pandemic has resulted in several things, namely $43 \%$ risk of a global economic slowdown, which made investors even more cautious, $42 \%$ of the JCI in the Indonesian capital market was observed to have sharply weakened to a position of around 3 years, the lowest was suppressed by investors who took a safe position, dragged down by negative regional sentiment, $45 \%$ weakening in the JCI in line with the performance of Asian stock markets Others who are compact in the red zone, $51 \%$ of the rupiah exchange rate against the dollar which is getting weaker will also shadow the market, $42 \%$ of foreign funds are still flowing out of the stock market, and $35 \%$ of foreign funds are still flowing out of the stock market. The performance of the capital market during the Covid-19 experienced several dynamics which resulted in investors feeling and experiencing $50 \%$ of share buybacks by Issuers or Public Companies without first obtaining approval from the GMS and the maximum number of shares proceeds. treasury stock was increased from $10 \%$ to $20 \%$ of paid-in capital, $59 \%$ of which occurred an extension of the deadline for submission of the 2019 Annual Financial Report, Annual Report for Issuers and Public Companies, including Listed Companies, which is two months from the deadline for submission. The $58 \%$ there was an extension of the deadline for submission of the Interim Financial Report I Year 2020 for Listed Companies for two months from the deadline for submission of reports as referred to in the IDX Regulations, 58\% extension of the deadline for holding the Annual GMS by Issuers and Public Companies for two months. The implementation of the GMS by a Public Company can be done by utilizing the Electronic Proxy facility in the E-GMS system.
Changes in Auto Rejection limits on the Trading Regulations on the Stock Exchange, and 51\% of the time there is a ban on Short Selling Transactions for all Exchange Members starting March 2 (2020) until the deadline 30-minute halt trading in the event that the JCI has decreased by $5 \%$. Adjustment of haircut values and risk calculations for market stimulation.

Table 3. Descriptive Statistics $(\mathrm{N}=100)$

\begin{tabular}{|c|c|c|c|c|}
\cline { 3 - 5 } \multicolumn{2}{c|}{} & $\begin{array}{c}\text { Stock } \\
\text { Price } \\
(\text { SP })\end{array}$ & $\begin{array}{c}\text { Covid-19 } \\
(\text { CO-19) }\end{array}$ & $\begin{array}{c}\text { Indonesia } \\
\text { Stock } \\
\text { Exchange } \\
(\text { IDX) }\end{array}$ \\
\hline $\mathrm{N}$ & Statistic & 1.00 & 1.00 & 1.00 \\
\hline Minimum & Statistic & 1.00 & 2.33 & 1.00 \\
\hline Maximum & Statistic & 5.00 & 5.00 & 5.00 \\
\hline Mean & Statistic & 3.47 & 3.97 & 3.67 \\
\hline $\begin{array}{c}\text { Std. } \\
\text { Deviation }\end{array}$ & Statistic & 0.642 & .577 & .685 \\
\hline Variance & Statistic & 41.235 & 33.341 & 46.159 \\
\hline \multirow{2}{*}{\begin{tabular}{c} 
Skewness \\
\cline { 2 - 5 }
\end{tabular}} & Statistic & -.00208 & -.00029 & -.00161 \\
\hline \multirow{2}{*}{ Kurtosis } & Std. Error & .0241 & .0241 & .0241 \\
\cline { 2 - 5 } & Statistic & .0219 & -.0319 & .0128 \\
\hline
\end{tabular}

(Source: Authors calculation)

Table 4. One-Sample Kolmogorov-Smirnov Test

\begin{tabular}{|c|c|c|}
\cline { 2 - 3 } \multicolumn{2}{c|}{} & Unstandardized Residual \\
\hline \multirow{2}{*}{$\begin{array}{c}\text { Normal } \\
\text { Parameters }\end{array}$} & $\mathrm{N}$ & 100 \\
\cline { 2 - 3 } & Mean & .0000000 \\
\hline \multirow{3}{*}{$\begin{array}{c}\text { Most Extreme } \\
\text { Differences }\end{array}$} & Absolute & 34.36425887 \\
\cline { 2 - 3 } & Positive & .068 \\
\cline { 2 - 3 } & Negative & .068 \\
\hline \multicolumn{2}{|c|}{ Test Statistic } & -.063 \\
\hline \multicolumn{2}{|c|}{ Asymp. Sig. (2-tailed) } & .068 \\
\hline
\end{tabular}

(Source: Authors calculation)

The performance of the capital market during the Covid- 19 experienced several dynamics which resulted in investors feeling and experiencing $50 \%$ of share buybacks by Issuers or Public Companies without first obtaining approval from the General Meeting of Shareholders (GMS) and the maximum number of shares proceeds. Treasury stock was increased from $10 \%$ to $20 \%$ of paid-in capital, $59 \%$ of which occurred an extension of the deadline for submission of the 2019 Annual Financial Report, Annual Report for Issuers and Public Companies, including Listed Companies, which is two months from the deadline for submission. The $58 \%$ there was an extension of the deadline for submission of the Interim Financial Report I Year 2020 for Listed Companies for two months from the deadline for submission of reports as referred to in the IDX Regulations, 58\% extension of the deadline for 
holding the Annual GMS by Issuers and Public Companies for two months. The implementation of the GMS by a Public Company can be done by utilizing the Electronic Proxy facility in the E-GMS system. Changes in Auto Rejection limits on the Trading Regulations on the Stock Exchange, and $51 \%$ of the time there is a ban on Short Selling Transactions for all Exchange Members starting March 2 (2020) until the deadline 30-minute halt trading in the event that the JCI has decreased by $5 \%$. Adjustment of haircut values and risk calculations for market stimulation.

The descriptive variables in this study include the mean value of stock prices, the Covid-19, and the capital market performance respectively $3.47,3.97$, and 3.67. Standard deviation of Investment Knowledge, stock price, Covid-19, capital market performance respectively $0.642,0.577$, and 0.685 . Stock price variance, capital market performance respectively $41,235,33,341$, and 46,159 . Stock price skewness, Covid-19, and capital market performance were $-0.00208,-0.00029$, and -0.0161 , respectively. Stock price kurtosis, and capital market performance respectively 0.0478 .

In the Kolmogorov-Smirnov One-Sample Table Test the absolute value of 0.068 unstandardized residuals with the Kolmogorov-Smirnov table on sample $\mathrm{N}=100$, namely 0.083 , then $0.068<0.083$, which means the data are normally distributed. This is evidenced by the results of the Kolmogorov-Smirnov statistical test in Table 4, which is to look at the Asymp value. Sig. (2 tailed) the value is $0.200>0.05$, which means that the data are normally distributed.

Model Summary and Coefficients, it can be seen that the $\mathrm{F}$ test of this model is significant $0.000<0.05$ with an F value of 141.077 meaning that this research model has fulfilled the goodness of fit model test which sees that the issuer's stock price and the impact of the Covid19 pandemic have a significant effect on the performance of the Indonesian capital market. The R-square value of the direct effect in this study of 0.744 indicates that the strength of the issuer's share price and the impact of the Covid-19 pandemic is able to explain and influence the performance variables of the Indonesian capital market by $74.7 \%$ of the total sample of 100 respondents in 2020 . This means that the variable share price of issuers and the impact of the Covid-19 can explain the capital market performance variable of 74.4 percent, while the remaining $25.6 \%$ is influenced by other variables outside of this study (see Table 5).

Table 5. ANOVA, Model Summary, and Coefficients

\begin{tabular}{|c|c|c|c|c|c|c|}
\hline \multicolumn{2}{|r|}{ Model } & Sum of Squares & df & Mean Square & $\mathrm{F}$ & Sig. \\
\hline \multirow{3}{*}{1} & Regression & 340066.674 & 2 & 170033.337 & 141.077 & $.000^{\mathrm{b}}$ \\
\hline & Residual & 116909.326 & 97 & 1205.251 & & \\
\hline & Total & 456976.000 & 99 & & & \\
\hline \multirow{2}{*}{\multicolumn{2}{|c|}{ Model }} & \multicolumn{2}{|c|}{ Unstandardized Coefficients } & Standardized Coefficients & \multirow{2}{*}{$\mathrm{t}$} & \multirow{2}{*}{ Sig. } \\
\hline & & $\mathrm{B}$ & Std. Error & Beta & & \\
\hline \multirow{3}{*}{1} & (Constant) & -30.956 & 24.713 & & $-1,253$ & .213 \\
\hline & Company stock prices & .516 & .070 & .488 & 7.409 & .000 \\
\hline & $\begin{array}{c}\text { Impact of Covid-19 } \\
\text { Pandemic }\end{array}$ & .551 & .078 & .468 & 7.109 & .000 \\
\hline Model & $\mathrm{R}$ & R Square & $\begin{array}{l}\text { Adjusted R } \\
\text { Square }\end{array}$ & Std. Error of the Estimate & Durbin-Watson & \\
\hline 1 & $.863^{\mathrm{a}}$ & .744 & .739 & 34.71672 & 1.866 & \\
\hline
\end{tabular}

(Source: Authors calculation) 
The T-test on the variable share price of the issuer and the impact of the Covid-19 is partially significant 0.000 $<0.005$ with a $\mathrm{T}$ value of 7.409 and 7.109 respectively, this means that part there is an effect on the issuer's share price and the impact of the Covid-19 partially which is significant and positive Indonesian capital market. And based on the table, the formula equation can be formed from the unstandardized coefficients:

$$
C M P_{t}=-30.956+0.516 I S P_{t}+0.551 I C P_{t}
$$

Where: CMP is Capital Market Performance, ISP is Issuer Share Price, ICP is Impact of the Covid-19 Pandemic, and tis time-series.

The interpretation of the regression is Constant (a) means that if all independent variables have a value of zero (0) then the value of the beta variable of the performance of the Indonesian capital market is $-30,956$, the value of the issuer's share price coefficient for variable $\mathrm{X} 1$ and the impact of the Covid-19 are respectively equal to 0.516 and 0.551 . This means that partially every increase in the share price of the issuer and the impact of the Covid-19 by one unit, the Beta (Y) variable will increase respectively $\mathrm{X} 1$ and $\mathrm{X} 2$ by 0.516 and 0.551 , assuming that the other independent variables of the regression model are fixed.

\section{Conclusions}

This study has fulfilled the feasibility of testing the qualitative analysis tools used to determine and analyze the conditions of capital market performance experienced by the FAC Indonesia investor community in Samarinda, East Kalimantan. This study found that the performance of the Indonesian capital market during the Covid-19 was felt that there were many buybacks by issuers but it was not balanced with the flow of public funds and the flow of funds from foreign investors who withdrew their funds from the Indonesian capital market. Improvements in the administration of accountability reports submission and adjustments to the extension of the time limit are some indicators of the performance of the Indonesian capital market as an effort to maintain liquidity stability by the IDX to survive this Covid19.

There are several issuers' stock prices that have experienced a drastic drop in terms of the decline in capital market performance. Public investors and foreign investors in certain stocks, especially in the consumer sector and various industries, conduct cash outflows from the capital market [35]. The cash outflow behavior motives carried out by public and foreign investors in this study were not studied, of course, there are several varied motives for them during the Covid-19. The stock market capitalization of issuers is dominated by the decline in stock prices in an unpredictable period of time, but stable correction due to the value, volume, and frequency of daily stock transactions, this makes the expectation of long-term investor stock returns persist because there are several listed shares. which can still provide dividends to their investors even though the issuer's share price has fallen sharply.

\section{Acknowledgements}

We are very grateful to the Department of Management (Faculty of Economics and Business, Mulawarman University) for the grant assistance for this study.

\section{REFERENCES}

[1] K. J. Heyden and T. Heyden, "Market Reactions to the Arrival and Containment of COVID-19: An Event Study," Financ. Res. Lett., p. 101745, In Press, 2020.

[2] A. A. Salisu and X. V. Vo, "Predicting stock returns in the presence of COVID-19 pandemic: The role of health news," Int. Rev. Financ. Anal., Vol. 71, p. 101546, 2020.

[3] D. I. Okorie and B. Lin, "Stock markets and the COVID-19 fractal contagion effects," Financ. Res. Lett., No. June, p. 101640, 2020.

[4] O. Erdem, "Freedom and stock market performance during Covid-19 outbreak," Financ. Res. Lett., Vol. 36, No. June, p. 101671, 2020.

[5] B. N. Ashraf, "Stock markets' reaction to COVID-19: Cases or fatalities?," Res. Int. Bus. Financ., Vol. 54, No. May, p. 101249, 2020.

[6] [P. He, Y. Sun, Y. Zhang, and T. Li, “COVID-19's Impact on Stock Prices Across Different Sectors-An Event Study Based on the Chinese Stock Market," Emerg. Mark. Financ. Trade, Vol. 56, No. 10, pp. 2198-2212, 2020.

[7] S. Baek, S. K. Mohanty, and M. Glambosky, "COVID-19 and stock market volatility: An industry level analysis," Financ. Res. Lett., No. August, p. 101748, 2020.

[8] D. Altig et al., "Economic uncertainty before and during the COVID-19 pandemic," J. Public Econ., Vol. 191, p. 104274 , 2020.

[9] M. Ali, N. Alam, and S. A. R. Rizvi, "Coronavirus (COVID-19) - An epidemic or pandemic for financial markets," J. Behav. Exp. Financ., Vol. 27, p. 100341, 2020.

[10] M. Topcu and O. S. Gulal, "The impact of COVID-19 on emerging stock markets," Financ. Res. Lett., Vol. 36, No. June, p. 101691, 2020.

[11] C. O. Cepoi, "Asymmetric dependence between stock market returns and news during COVID-19 financial turmoil," Financ. Res. Lett., Vol. 36, No. June, p. 101658 , 2020.

[12] H. J. Song, J. Yeon, and S. Lee, "Impact of the COVID-19 pandemic: Evidence from the U.S. restaurant industry," Int. J. Hosp. Manag., Vol. 92, No. June 2020, p. 102702, 2021.

[13] P. D. Alexakis and I. G. Samantas, "Foreign ownership and 
market power: The special case of European banks," J. Bank. Financ., Vol. 118, 2020.

[14] F. Aslam, S. Aziz, D. K. Nguyen, K. S. Mughal, and M. Khan, "On the efficiency of foreign exchange markets in times of the COVID-19 pandemic," Technol. Forecast. Soc. Change, Vol. 161, No. June, p. 120261, 2020.

[15] M. Dunford and B. Qi, "Global reset: COVID-19, systemic rivalry and the global order," Res. Glob., Vol. 2, No. May, p. $100021,2020$.

[16] T. Griffith, B. Roseman, and D. Shang, "The effects of an increase in equity tick size on stock and option transaction costs," J. Bank. Financ., Vol. 114, 2020.

[17] J. Brzeszczyński and B. M. Ibrahim, “A stock market trading system based on foreign and domestic information," Expert Syst. Appl., Vol. 118, pp. 381-399, 2019.

[18] D. Chen, L. F. S. Wang, and J. yao Lee, "Foreign ownership, privatization and subsidization with shadow cost of public funds," North Am. J. Econ. Financ., Vol. 50, No. July, pp. 1$11,2019$.

[19] J. Becker, D. Hopp, and M. Kriebel, "Mental accounting of public funds - The flypaper effect in the lab," J. Econ. Behav. Organ., Vol. 176, pp. 321-336, 2020.

[20] A. Dayanandan, H. Donker, S. Kuntluru, and J. Nofsinger, Share buybacks in India, Vol. 54. Elsevier B.V., 2020.

[21] R. Sonika and M. B. Shackleton, "Buyback behaviour and the option funding hypothesis," J. Bank. Financ., Vol. 114, 2020.

[22] Z. Tang, M. Ran, and Y. Zhao, "Stock trading dynamics and pedestrian counterflows: Analogies and differences," North Am. J. Econ. Financ., Vol. 54, p. 101015, 2019.

[23] Y. Shi, M. Yu, L. Chen, P. C. Ivanov, and Y. Wang, "Quantifying financial market dynamics: Scaling law in rank mobility of Chinese stock prices," Financ. Res. Lett., No. November 2019, p. 101516, 2020.

[24] Z. xiong Huang, Q. Tang, and S. Huang, "Foreign investors and stock price crash risk: Evidence from China," Econ. Anal. Policy, Vol. 68, pp. 210-223, 2020.
[25] S. Amini, A. Buchner, C. X. Cai, and A. Mohamed, "Why do firms manage their stock price levels?," J. Int. Financ. Mark. Institutions Money, Vol. 67, p. 101220, 2020.

[26] B. Ahmed, "Understanding the impact of investor sentiment on the price formation process: A review of the conduct of American stock markets," J. Econ. Asymmetries, Vol. 22, No. June, p. e00172, 2020.

[27] H. Fan, "When consumer type matters: Price effects of the United-Continental merger in the airline industry," Econ. Transp., Vol. 21, No. December 2019, p. 100154, 2020.

[28] J. Gim and S. C. (Shawn) Jang, "Share repurchases and stock market reactions: Messages from the restaurant industry," Int. J. Hosp. Manag., Vol. 86, No. November 2019, p. 102457, 2020.

[29] A. Dias, "Market capitalization and Value-at-Risk," J. Bank. Financ., Vol. 37, No. 12, pp. 5248-5260, 2013.

[30] M. P. Kumar and N. V. M. Kumara, "Market capitalization: Pre and post COVID-19 analysis," Mater. Today Proc., Vol. 8, No. p/33052307, 2020.

[31] I. C. Tsai, "The source of global stock market risk: A viewpoint of economic policy uncertainty," Econ. Model., Vol. 60, No. September 2016, pp. 122-131, 2017.

[32] J. M. González-Méijome, "Journal of Optometry in Emerging Sources Citation Index (ESCI) and peer-review process during COVID-19 pandemic," J. Optom., Vol. 13, No. 4, pp. 213-215, 2020.

[33] L. Diana, D. C. Darma, S. Amalia, and S. Made, "International Journal of Business and Management," International Journal of Business and Management., Vol. 8, No. 2, pp. 86-92, 2020.

[34] S. Amalia, D. C. Darma, and Siti Maria, "Supply Chain Management and the Covid-19 Outbreak: Optimizing its Role for Indonesia," Current Research Journal of Social Sciences and Humanities, Vol. 3, No. 2, pp. 196-202, 2020.

[35] M. Ikbal, I. Irwansyah, A. Paminto, Y. Ulfah, and D. C. Darma, "Explores the Specific Context of Financial Statement Fraud Based on Empirical from Indonesia," Universal Journal of Accounting and Finance, Vol. 8, No. 2, pp. $29-40,2020$. 